BIOFARM

Jurnal Ilmiah Pertanian

ISSN Print: 0216-5430; ISSN Online: 2301-6442

Vol. 15, No. 2, Oktober 2019

\title{
Pengaruh Konsentrasi dan Interval Pemberian PGPR (Plant Growth Promoting Rhizobacteria) Terhadap Pertumbuhan dan Produksi Bunga Kol (Brassica oleraceae var. botrytis L.)
}

\author{
The Effect of Concentration and Interval Application of PGPR (Plant Growth \\ Promoting Rhizobacteria) on The Growth and Production of Cauliflower \\ (Brassica oleraceae Var. Botrytis L.)
}

Hany Anisa*

Laboratorium Pengamatan Hama dan Penyakit (LPHP) Pemalang

*Korespondensi Penulis: hanyanisa01@gmail.com

\begin{abstract}
ABSTRAK
Penelitian bertujuan untuk mengetahui pengaruh konsentrasi dan interval pemberian PGPR terhadap pertumbuhan dan produksi bunga kol (Brassica oleraceae Var. Botrytis L.). Penelitian dilakukan di Desa Kadipaten, Kecamatan Wiradesa Kabupaten Pekalongan pada bulan Februari sampai Juni 2019 dengan Rancangan Acak Kelompok (RAK) faktorial. Faktor pertama adalah konsentrasi PGPR terdiri dari 4 taraf yaitu $0 \mathrm{ml} / \mathrm{l}, 2,5 \mathrm{ml} / \mathrm{l}, 5 \mathrm{ml} / \mathrm{l}$, dan $7,5 \mathrm{ml} / \mathrm{l}$, sedangkan faktor kedua adalah interval pemberian PGPR terdiri dari 3 taraf yaitu 1, 2, dan 3 minggu sekali dengan ulangan tiga kali. Data dianalisis dengan Uji F, apabila terdapat beda nyata antar perlakuan, maka dilakukan uji lanjut dengan uji BNT 5\%. Hasil penelitian menunjukan bahwa konsentrasi PGPR berbeda sangat nyata pada variabel saat muncul krop bunga, bobot segar brangkasan, luas daun terluas, bobot segar akar, dan bobot krop bunga, sedangkan berbeda nyata pada variabel panjang akar tepanjang, bobot kering akar, dan diameter krop bunga. Konsentrasi terbaik adalah $5 \mathrm{ml} / \mathrm{l}$ air. Perlakuan interval pemberian PGPR berbeda sangat nyata pada variabel saat muncul krop bunga, luas daun terluas, bobot segar akar, bobot kering akar, dan bobot krop bunga, sedangkan berbeda nyata pada variabel tinggi tanaman, jumlah daun, dan diameter krop bunga. Interval pemberian PGPR terbaik adalah 2 minggu sekali. Terdapat interaksi antara konsentrasi dan interval pemberian PGPR pada variabel bobot segar brangkasan dan bobot segar akar. Interaksi terbaik diperoleh perlakuan konsentrasi PGPR $5 \mathrm{ml} / \mathrm{l}$ air dan interval pemberian PGPR 2 minggu sekali.
\end{abstract}

Kata kunci: Konsentrasi, Interval Pemberian PGPR, Bunga Kol

\section{ABSTRACT}

The study aims to determine the effect of concentration and interval application of PGPR on the growth and production of cauliflower (Brassica oleraceae Var. Botrytis L.). The study was conducted in the Kadipaten Village, Wiradesa District, Pekalongan Regency from February to June 2019 with a factorial Randomized Block Design (RBD). The first factor is the concentration of PGPR consisting of 4 levels, namely $0 \mathrm{ml} / \mathrm{l}, 2.5 \mathrm{ml} / \mathrm{l}, 5 \mathrm{ml} / \mathrm{l}$, and $7.5 \mathrm{ml} / \mathrm{l}$, while the second factor is the interval of PGPR application consisting of 3 levels namely 1,2 , and 3 weeks with three replications. Data were analyzed by $F$ test, if there were significant differences between treatments, then further tests were performed with a 5\% LSD test. The results showed that the concentration of PGPR was significantly different in variables when flower heads appeared, stover fresh weight, widest leaf area, root fresh weight, and flower head weight, while significantly different in variables root length, root dry weight, and flower head diameter. The best concentration is $5 \mathrm{ml} / \mathrm{I}$ of water. The treatment interval of PGPR application was significantly different in variables when flower heads appeared, the widest leaf area, root fresh weight, root dry weight, and flower head weight, while significantly different in plant height, number of leaves, and flower head diameter. The best PGPR application interval is 2 weeks. There was an interaction between the concentration and interval of PGPR application on the stover fresh weight variable and root fresh weight. The best interaction was obtained in the treatment of PGPR concentration of $5 \mathrm{ml} /$ / of water and the interval of application of PGPR every 2 weeks.

Keywords: Concentration, application interval of PGPR, cauliflower

\section{PENDAHULUAN}

Bunga kol merupakan tanaman pertanian yang tergolong famili Cruciferae yang memproduksi bunga. Krop bunga yang dapat dimakan disebut curd, terdiri atas 5.000 kuntum bunga atau lebih dengan tangkai pendek sehingga terlihat membulat, lunak, tebal, berwarna putih kekuningan. Curd bunga kol mempunyai nilai kesehatan dan farmasi yang baik. Kandungan gizi dalam curd cukup bervariasi, demikian pula 
dengan metabolit sekundernya yang antara lain adalah sulfoksida S-metilsistein dan sulforafan. (Widiatningrum dan Krispinus, 2010).

Beberapa tahun produktivitas bunga kol di Jawa Tengah mengalami fluktuatif. Pada tahun 2012 produktivitas bunga kol sebanyak 92,79 kuintal/ Ha. Pada tahun 2013 meningkat menjadi 99,38 kuintal/ $\mathrm{Ha}$, dan pada tahun 2014 menurunmenjadi 98,27 kuintal/ Ha. Pada tahun 2015 mengalami penurunan lagi menjadi 90,01 kuintal/ $\mathrm{Ha}$. Hal tersebut dikarenakan luas panen mengalami fluktuatif. Pada tahun 2016 produktivitas bunga kol mengalami kenaikan menjadi 98,77 kuintal/ Ha (Dinas Pertanian dan Perkebunan, 2017). Potensi produktivitas bunga kol di Indonesia dapat mencapai 20-30 ton/ha (Utami, dkk., 2016).

Kebutuhan dan peranan bunga kol yang besar untuk kebutuhan setiap hari, maka upaya untuk meningkatkan pertumbuhan dan produksi tanaman bunga kol sangat penting. Untuk memenuhi kebutuhan sayuran bunga kol dapat dilakukan budidaya tanaman dengan pemberian Rhizobakteri pemacu tumbuh tanaman yang lebih populer disebut PGPR, merupakan kelompok bakteri yang menguntungkan yang secara aktif mengkolonisasi rizosfir (Rahni, 2012).

PGPR berperan penting dalam meningkatkan pertumbuhan tanaman, hasil panen, dan kesuburan lahan (Naihati, dkk., 2018). Secara langsung, PGPR merangsang pertumbuhan tanaman dengan menghasilkan hormon pertumbuhan, vitamin, dan berbagai asam organik serta meningkatkan asupan nutrisi bagi tanaman. Pertumbuhan tanaman ditingkatkan secara tidak langsung oleh PGPR melalui kemampuannya dalam menghasilkan antimikroba patogen yang dapat menekan pertumbuhan fungi penyebab penyakit tumbuhan (fitopatogenik) dan siderophore (Rahni, 2012). Formula PGPR yang diintroduksi ke pertanaman budidaya dapat bersumber dari perakaran bambu, rumput gajah atau putri malu (Iswati, 2012).

Beberapa penelitian telah membuktikan bahwa PGPR berpengaruh terhadap pertumbuhan dan hasil berbagai tanaman sayuran. Konsentrasi PGPR $5 \mathrm{ml} / \mathrm{l}$ pada tanaman bawang daun menunjukkan hasil yang baik (Sukarno, 2014). Tanaman hortikultura dianjurkan sebanyak $5 \mathrm{ml} / \mathrm{l}$ air tiap 2 minggu sekali (Vandalisna dan Mulyono, 2015). Pemberian variasi aplikasi
PGPR dengan interval penyiraman 2 minggu sekali memberikan hasil terbaik terhadap pertumbuhan tanaman selada (Naikofi dan Rusae, 2017).

Aplikasi PGPR yang tepat untuk meningkatkan produktivitas tanaman bunga kol dataran rendah di Jawa Tengah belum diketahui, sehingga perlu dilakukan penelitian mengenai teknik budidaya. Teknik budidaya yang perlu dilakukan adalah perbaikan kualitas melalui konsentrasi dan interval pemberian PGPR sebagai nutrisi pendukung yang dibutuhkan tanaman bunga kol, sehingga PGPR dimungkinkan mampu meningkatkan pertumbuhan dan produksi tanaman bunga kol.

Berdasarkan uraian di atas, maka dilakukan penelitian yang bertujuan untuk mengetahui konsentrasi PGPR optimum yang mampu meningkatkan pertumbuhan dan produksi bunga kol, mengetahui interval pemberian PGPR yang paling tepat meningkatkan pertumbuhan dan produksi bunga kol dan mengetahui interaksi antara konsentrasi dan interval pemberian PGPR terhadap peningkatan pertumbuhan dan produksi bunga kol.

\section{METODE PENELITIAN}

Penelitian ini telah dilaksanakan di Desa Kadipaten Kecamatan Wiradesa Kabupaten Pekalongan dengan ketinggian wilayah \pm 10 meter di atas permukaan laut (dpl). Penelitian ini telah dimulai pada bulan Februari sampai dengan Juni 2019. Rancangan yang digunakan pada penelitian ini adalah Rancangan Acak Kelompok (RAK). Percobaan ini merupakan percobaan faktorial yang terdiri atas 2 faktor. Faktor pertama adalah konsentrasi PGPR yaitu $0 \mathrm{ml} / \mathrm{l}(\mathrm{K} 0)$, $2,5 \mathrm{ml} / \mathrm{l}(\mathrm{K} 1), 5 \mathrm{ml} / \mathrm{l}(\mathrm{K} 2)$, dan 7,5 ml/l (K3). Faktor kedua yaitu interval pemberian PGPR: 1 minggu sekali (I1), 2 minggu sekali (I2), 3 minggu sekali (I3). Kombinasi perlakuan ada 12, masing-masing kombinasi diulang tiga kali sehingga seluruhnya ada $(4 \times 3) \times 3=36$ satuan percobaan.

Data yang diperoleh dianalisis menggunakan uji F. Jika antara faktor yang dicoba terdapat perbedaan nyata, maka analisis dilanjutkan uji BNT, untuk perlakuan faktor konsentrasi PGPR diuji menggunakan regresi dan untuk faktor interval pemberian PGPR diuji menggunakan kontras orthogonal.

Variabel yang diamati meliputi: (1) tinggi tanaman, (2) jumlah daun, (3) saat 
muncul krop bunga, (4) bobot segar brangkasan, (5) luas daun terluas, (6) bobot segar akar, (7) bobot kering akar, (8) panjang akar terpanjang, (9) bobot krop bunga, (10) diameter krop bunga.

\section{HASIL DAN PEMBAHASAN Konsentrasi PGPR}

Hasil penelitian menunjukkan bahwa perlakuan konsentrasi PGPR berbeda sangat nyata terhadap semua variabel, kecuali berbeda nyata pada variabel bobot kering akar, diameter krop bunga, panjang akar terpanjang dan tidak berbeda nyata pada variabel tinggi tanaman dan jumlah daun. Konsentrasi PGPR $5 \mathrm{ml} / \mathrm{l}$ (K2) merupakan konsentrasi optimum untuk pertumbuhan dan produksi bunga kol. Variabel bobot segar brangkasan, luas daun terluas, bobot segar akar, bobot kering akar, bobot krop bunga, diameter krop bunga pada perlakuan konsentrasi PGPR memiliki persamaan kuadratik dengan titik optimumnya dicapai pada konsentrasi $\pm 5 \mathrm{ml} / \mathrm{l}$. Hasil ini sesuai dengan hipotesis yang menyebutkan konsentrasi optimum untuk pertumbuhan dan produksi bunga kol yaitu pada konsentrasi 5 $\mathrm{ml} / \mathrm{l}$.

Tabel 1. Angka rata-rata dan Analisis Statistik Data Penelitian Pengaruh Konsentrasi dan Interval Pemberian PGPR

\begin{tabular}{cccccc}
\hline & Tinggi & Jumlah daun & Saat muncul & Bobot segar & Luas daun \\
Perlakuan & tanaman $(\mathrm{cm})$ & (helai) & $\begin{array}{c}\text { krop } \\
\text { brangkasan terluas }\left(\mathrm{cm}^{2}\right) \\
\text { (HST) }\end{array}$ & \begin{tabular}{c} 
(gram) \\
\hline
\end{tabular} \\
\hline
\end{tabular}

Konsentrasi PGPR

\begin{tabular}{|c|c|c|c|c|c|}
\hline $\mathrm{K} 0=0 \mathrm{ml} / \mathrm{l}$ & 54,18 & 18,02 & $65,82 \mathrm{~b}$ & 203,73 a & $171,90 \mathrm{a}$ \\
\hline $\mathrm{K} 1=2,5 \mathrm{ml} / \mathrm{l}$ & 54,21 & 17,96 & $63,36 \mathrm{a}$ & $229,41 \mathrm{c}$ & $190,20 \mathrm{~b}$ \\
\hline $\mathrm{K} 2=5 \mathrm{ml} / \mathrm{l}$ & 51,87 & 18,27 & $60,40 \mathrm{a}$ & $228,12 b$ & $200,08 \mathrm{c}$ \\
\hline $\mathrm{K} 3=7,5 \mathrm{ml} / \mathrm{l}$ & 53,59 & 18,47 & $61,11 \mathrm{a}$ & $225,79 \mathrm{~b}$ & $186,61 \mathrm{~b}$ \\
\hline \multicolumn{6}{|l|}{$\begin{array}{l}\text { Interval pemberian } \\
\text { PGPR }\end{array}$} \\
\hline 11 = 1 minggu sekali & 55,02 & $17,87 \mathrm{a}$ & $64,12 \mathrm{~b}$ & 217,47 a & $190,67 \mathrm{~b}$ \\
\hline $\mathrm{I} 2$ = 2 minggu sekali & 50,57 & $18,68 \mathrm{~b}$ & $60,07 \mathrm{a}$ & 228,68 b & $190,23 \mathrm{~b}$ \\
\hline $13=3$ minggu sekali & 54,80 & $17,98 \mathrm{a}$ & $63,83 \mathrm{~b}$ & $219,13 \mathrm{a}$ & $180,69 \mathrm{a}$ \\
\hline
\end{tabular}

Pemberian PGPR tampak berbeda sangat nyata pada variabel bobot krop bunga. Pada konsentrasi $5 \mathrm{ml} / \mathrm{l}$ diduga dapat meningkatkan bobot krop bunga karena bakteri pada PGPR dapat melarutkan pupuk $P$ sehingga penyerapan unsur hara $P$ menjadi maksimal. Marom, dkk., (2017) menyatakan bahwa bakteri PGPR berfungsi melarutkan dan meningkatkan ketersediaan unsur $P$ dalam tanah. Unsur hara $P$ bermanfaat untuk memperbaiki pembungaan dan pembentukan buah. Altomare, dkk., (1999) mengatakan bahwa PGPR merupakan bakteri yang dapat menyediakan fosfat terikat menjadi fosfat yang dapat terlarut sehingga dapat diserap oleh tanaman. Febriyanti, dkk, (2015) menyatakan bahwa penambahan PGPR menghasilkan bobot basah polong kacang tanah berbeda nyata dibandingkan perlakuan kontrol (tanpa PGPR).

Konsentrasi PGPR berpengaruh pada pertumbuhan dan produksi bunga kol. Menurut (Naikofi dan Rusae, 2017) PGPR merupakan konsorsium bakteri yang aktif mengkolonisasi akar tanaman yang berperan penting dalam meningkatkan pertumbuhan tanaman, hasil panen, dan kesuburan lahan. Husnihuda, dkk., (2017) mengatakan bahwa PGPR sebagai biofertilizer dapat menjaga kesuburan tanah maka unsur hara dalam tanah dapat tercukupi sehingga mempengaruhi fotosintesis dan berakibat pada meningkatnya pertumbuhan vegetatif. Hal ini dapat terlihat dimana aplikasi PGPR secara nyata berpengaruh terhadap berat segar akar dan berat kering akar. 
Pengaruh Interval Pemberian PGPR

Hasil penelitian menunjukkan bahwa perlakuan interval pemberian PGPR berbeda sangat nyata terhadap semua variabel yang diamati, kecuali berbeda nyata pada variabel tinggi tanaman, jumlah daun, diameter krop bunga dan tidak berbeda nyata pada variabel bobot segar brangkasan dan panjang akar terpanjang. Interval pemberian PGPR 2 minggu sekali memberikan hasil terbaik dalam pertumbuhan dan produksi bunga kol. Tanaman bunga kol yang diberi perlakuan

Tabel 2. Angka rata-rata dan Analisis Statistik Data Penelitian Pengaruh Konsentrasi dan Interval Pemberian PGPR.

\begin{tabular}{cccccc}
\hline Perlakuan & Panjang akar & $\begin{array}{c}\text { Bobot } \\
\text { terpanjang }(\mathrm{cm})\end{array}$ & $\begin{array}{c}\text { Bobot kering } \\
\text { segar akar } \\
\text { (gram) }\end{array}$ & $\begin{array}{c}\text { Bobot krop } \\
\text { bunga } \\
\text { (gram) }\end{array}$ & $\begin{array}{c}\text { Diameter } \\
\text { krop bunga } \\
(\mathrm{cm})\end{array}$ \\
\hline
\end{tabular}

\begin{tabular}{|c|c|c|c|c|c|}
\hline \multicolumn{6}{|l|}{ Konsentrasi PGPR } \\
\hline $\mathrm{K} 0=0 \mathrm{ml} / \mathrm{l}$ & 20,81 & 29,48 a & $10,51 \mathrm{a}$ & $122,16 \mathrm{a}$ & $11,26 \mathrm{a}$ \\
\hline $\mathrm{K} 1=2,5 \mathrm{ml} / \mathrm{l}$ & 21,28 & $32,54 \mathrm{a}$ & $10,75 \mathrm{a}$ & $135,81 \mathrm{~b}$ & $11,55 a$ \\
\hline $\mathrm{K} 2=5 \mathrm{ml} / \mathrm{l}$ & 23,21 & $35,63 \mathrm{~b}$ & $12,37 \mathrm{~b}$ & $143,06 \mathrm{c}$ & $12,25 b$ \\
\hline $\mathrm{K} 3=7,5 \mathrm{ml} / \mathrm{l}$ & 22,59 & $30,58 \mathrm{a}$ & $10,64 \mathrm{a}$ & $139,32 \mathrm{~b}$ & $11,86 \mathrm{~b}$ \\
\hline \multicolumn{6}{|l|}{$\begin{array}{l}\text { Interval pemberian } \\
\text { PGPR }\end{array}$} \\
\hline I1 = 1 minggu sekali & 21,47 & $31,77 \mathrm{a}$ & $10,60 \mathrm{a}$ & $130,55 \mathrm{a}$ & $11,54 \mathrm{a}$ \\
\hline I2 = 2 minggu sekali & 22,79 & $35,24 \mathrm{~b}$ & $12,06 \mathrm{~b}$ & $141,97 \mathrm{~b}$ & $11,99 \mathrm{~b}$ \\
\hline I3 = 3 minggu sekali & 21,66 & $29,16 \mathrm{a}$ & $10,54 \mathrm{a}$ & $132,75 \mathrm{a}$ & $11,66 \mathrm{a}$ \\
\hline
\end{tabular}

interval pemberian PGPR 2 minggu sekali menghasilkan tanaman dengan ciri fisik memiliki jumlah daun yang banyak, permukaan daun luas, saat muncul bunga cepat, akar berjumlah banyak, bobot krop bunga berat, dan diameter krop bunga lebar.

Pemberian PGPR tampak berbeda sangat nyata pada variabel saat muncul krop bunga dan bobot krop bunga. Pada interval pemberian 2 minggu sekali diduga dapat mempercepat proses pembungaan dan meningkatkan bobot krop bunga karena bakteri akan membantu tanaman dalampenyerapan dan memenuhi kebutuhan unsur haranya. Marom, dkk., (2017) menyatakan bahwa bakteri PGPR berfungsi melarutkan dan meningkatkan ketersediaan unsur Phosphor (P) dan Mangan (Mn) dalam tanah serta meningkatkan kemampuan tanaman dalam menyerap unsur Sulfur (S).

Tersedianya unsur hara fosfor maka akan mempercepat pembungaan. Rohmawati, dkk., (2019) dalam penelitiannya menyatakan bahwa PGPR berpengaruh nyata terhadap umur berbunga, umur berbuah, umur panen pertama, dan bobot buah per tanaman dengan perlakuan PGPR.

PGPR yang merupakan kelompok bakteri yang dimanfaatkan sebagai pupuk hayati untuk membantu tanaman dalam suplai hara dan memperkuat tanaman terhadap serangan hama maupun penyakit tanaman (Naihati dan Rusae, 2018), sehingga pemberian PGPR dengan interval yang tepat memberikan pertumbuhan dan hasil produksi bunga kol yang terbaik.

Interval pemberian PGPR berguna bagi kesuburan tanah berfungsi memperbaiki sifat fisik tanah sehingga tekstur dan struktur tanah menjadi gembur, memperbaiki sifat kimia tanah karena PGPR dapat menstimulasi fitohormon dan mendukung proses kapasitas pertukaran kation dan memperbaiki sifat biologi tanah aktivitas mikroorganisme tanah meningkat (Husnihuda, dkk., 2017). Hal ini berakibat pada meningkatnya unsur hara makro dan mikro. Sehingga pertumbuhan menjadi meningkat mendukung proses fotosintesis tanaman. Proses fotosintesis menghasilkan 
Tabel 3. Angka rata-rata Interaksi Penelitian Pengaruh Konsentrasi dan Interval Pemberian PGPR. Perlakuan $\quad$ Bobot Segar Brangkasan (gram) Bobot Segar Akar (gram)

\begin{tabular}{|c|c|c|}
\hline Kol1 & $202,50 \mathrm{a}$ & $29,00 \mathrm{abc}$ \\
\hline KOI2 & $209,52 a b$ & $34,57 \mathrm{~cd}$ \\
\hline KOI3 & $199,16 \mathrm{a}$ & $24,86 a$ \\
\hline K1I1 & 243,95 ef & $37,24 d$ \\
\hline $\mathrm{K} 1 \mathrm{I} 2$ & 227,21 bcdef & $32,69 \mathrm{bcd}$ \\
\hline K1I3 & $217,07 \mathrm{abcd}$ & $27,69 a b$ \\
\hline K2I1 & 213,77 abc & $34,42 \mathrm{~cd}$ \\
\hline K2I2 & $246,05 \mathrm{f}$ & $37,49 d$ \\
\hline K2I3 & $224,54 \mathrm{bcde}$ & $34,98 \mathrm{~cd}$ \\
\hline K3I1 & $209,66 a b$ & $26,41 \mathrm{a}$ \\
\hline K3I2 & 231,95 cdef & $36,23 d$ \\
\hline K3।3 & 235,74 def & $29,11 \mathrm{abc}$ \\
\hline
\end{tabular}

Keterangan : Angka yang diikuti huruf yang sama pada kolom dan baris menunjukkan tidak berbeda nyata menurut uji BNT taraf $5 \%$

fotosintat yang tinggi menyebabkan perkembangan generatif tanaman sehingga bobot dan diameter krop dapat meningkat.

\section{Interaksi Antara Konsentrasi dan Interval Pemberian PGPR}

Hasil penelitian menunjukkan terdapat interaksi berbeda sangat nyata antara konsentrasi dan interval pemberian PGPR pada variabel bobot segar brangkasan dan berbeda nyata pada variabel bobot segar akar. Interaksi terbaik dicapai pada konsentrasi $5 \mathrm{ml} / \mathrm{l}$ dengan interval pemberian PGPR 2 minggu sekali (K2I2). Interaksi terjadi apabila antara perlakuan macam dan konsentrasi zat pengatur tumbuh saling memberikan pengaruh. Seperti dikemukakan oleh Gomez dan Gomez (1995), bahwa dua faktor dikatakan berinteraksi apabila pengaruh suatu faktor perlakuan berubah pada saat perubahan taraf faktor perlakuan lainnya. Selanjutnya dinyatakan oleh Steel dan Torrie (1991), bahwa bila pengaruh interaksi berbeda tidak nyata maka disimpulkan bahwa diantara faktor perlakuan tersebut bertindak bebas satu sama lainnya.

Menurut hasil penelitian interaksi terjadi pada perlakuan konsentrasi $5 \mathrm{ml} / \mathrm{l}$ dengan interval pemberian PGPR 2 minggu sekali (K2I2) yaitu bobot segar brangkasan. Hal ini menunjukkan antara konsentrasi $5 \mathrm{ml} / \mathrm{l}$ dengan interval pemberian PGPR 2 minggu sekali saling mempengaruhi dalam pertumbuhan tanaman bunga kol.

Aktivitas PGPR yang bekerja di dalam tanah sekitar perakaran tanaman dalam menyediakan unsur hara yang berperan sebagai penyedia nutrisi bagi tanaman. Akar menentukan kemampuan tanaman untuk menyerap unsur hara dan air, sehingga mempengaruhi pertumbuhan tanaman akibatnya fotosintesis meningkat. Proses fotosintesis meningkatkan pertumbuhan vegetatif dan generatif (Husnihuda, dkk., 2017). Pertumbuhan vegetatif yang baik menyebabkan bobot segar brangkasan dan akar bunga kol menjadi tinggi.

Interaksi konsentrasi dan interval pemberian PGPR tidak berpengaruh nyata terhadap beberapa variabel. $\mathrm{Hal}$ ini dikarenakan adanya akumulasi senyawa organik yang berhasil disintesis tanaman antar perlakuan adalah sama (Ningsih, dkk., 2018).

\section{Simpulan}

Berdasarkan hasil penelitian dan pembahasan dapat ditarik beberapa simpulan sebagai berikut:

1. Konsentrasi PGPR berbeda sangat nyata terhadap variabel saat muncul krop bunga, bobot segar brangkasan, luas daun terluas, bobot segar akar, dan bobot krop bunga, berbeda nyata pada variabel panjang akar terpanjang, bobot kering akar, diameter krop bunga dan berbeda tidak nyata pada variabel tinggi tanaman dan jumlah daun. Konsentrasi PGPR $5 \mathrm{ml} / \mathrm{l} \quad$ (K2) merupakan konsentrasi terbaik untuk pertumbuhan dan produksi bunga 
kol. Konsentrasi optimumnya adalah $5,44 \mathrm{ml} / \mathrm{l}$.

2. Interval pemberian PGPR berbeda sangat nyata terhadap variabel saat muncul krop bunga, luas daun terluas, bobot segar akar, bobot kering akar, dan bobot krop bunga, berbeda nyata pada variabel tinggi tanaman, jumlah daun, diameter krop bunga dan tidak berbeda nyata pada variabel bobot segar brangkasan dan panjang akar terpanjang. Interval pemberian PGPR 2 minggu sekali memberikan hasil terbaik dalam pertumbuhan dan produksi bunga kol.

3. Interaksi berbeda nyata antara konsentrasi dan interval pemberian PGPR pada variabel bobot segar brangkasan dan bobot segar akar. Interaksi terbaik dicapai pada konsentrasi $5 \mathrm{ml} / /$ dengan interval pemberian PGPR 2 minggu sekali (K2I2).

\section{DAFTAR PUSTAKA}

Altomare, C., W.A. Norvell, T. Bjorkman, GE. Harman. 1999. Solubilization of phophates and micronutrient by $P G P R$ and biocontrol fungus Trichoderma Harzianum Rifai 129522 Appl Environ Microbiol 65:29261933

Dinas Pertanian dan Perkebunan. 2017. Statistik Hortikultura Provinsi Jawa Tengah 2016. Jawa Tengah.

Febriyanti, L.E., M. Martosudiro, dan T. Hadiastono. 2015. Pengaruh Plant Growth Promoting Rhizobacteria (PGPR) terhadap Infeksi Peanut Stripe Virus (PStV), Pertumbuhan dan Produksi Tanaman Kacang Tanah (Arachis hypogaea L.) Varietas Gajah. Jurnal Hama dan Penyakit Tumbuhan. 3 (1), 84

Gomez, K.A. dan A.A. Gomez. 1995. Prosedur Statistika untuk Penelitian Pertanian

(Terjemahan

A.Sjamsuddin dan J.S. Baharsyah). Edisi Kedua. UIPress, Jakarta.
Husnihuda, M.I., R. Sarwitri, dan Y. E. Susilowati. 2017. Respon Pertumbuhan dan Hasil Kubis Bunga (Brassica oleracea var. Botrytis L.) pada Pemberian PGPR Akar Bambu dan Komposisi Media Tanam. Jurnal IImu Pertanian Tropika dan Subtropika 2 (1) : 1316.

Iswati, R. 2012. Pengaruh Dosis Formula PGPR Asal Perakaran Bambu terhadap Pertumbuhan Tanaman Tomat (Solanum lycopersicum syn). JATT Vol. 1 No. 1: 9-12

Marom, N., Rizal, M. Bintoro. 2017. Uji Efektivitas Waktu Pemberian dan Konsentrasi PGPR (Plant Growth Promoting Rhizobacteria) terhadap Produksi dan Mutu Benih Kacang Tanah (Arachis hypogaea L.). Agriprima. Journal of Applied Agricultural Sciences Vol. 1 No. 2:174-184

Naihati, Y.F., R.I.C.O. Taolin, dan A. Rusae. 2018. Pengaruh Takaran dan Frekuensi Aplikasi PGPR terhadap Pertumbuhan dan Hasil Tanaman Selada (Lactuca sativa L.). Jurnal Pertanian Konservasi Lahan Kering 3(1) 1-3

Naikofi, Y.M. dan A. Rusae. 2017. Pengaruh Aplikasi PGPR dan Jenis Pestisida terhadap Pertumbuhan dan Hasil Tanaman Selada (Lactuca sativa L.). Jurnal Pertanian Konservasi Lahan Kering 2 (4) 71- 73

Ningsih, Y.F., D. Armita, dan M. D. Maghfoer. 2018. Pengaruh Konsentrasi dan Interval Pemberian PGPR terhadap Pertumbuhan dan Hasil Buncis Tegak (Phaseolus vulgaris L.). Jurnal Produksi Tanaman Vol. 6 No. 7 
Rahni, N. M. 2012. Efek Fitohormon PGPR terhadap Pertumbuhan Tanaman Jagung (Zea mays).Jurnal Agribisnis dan Pengembangan Wilayah Volume 3. Universitas Haluoleo.

Rohmawati, F.A., R. Soelistyono, dan K. Koesriharti. 2019. Pengaruh Pemberian PGPR (Plant Growth Promothing Rhizobacteria)dan Kompos Kotoran Kelinci terhadap Hasil Tanaman Terung (solanum Melongena L.). Jurnal Produksi Tanaman.

Steel, R.G.D. \& J.H. Torrie. 1991. Prinsip dan Prosedur Statistika: Suatu Pendekatan Biometrik (Terjemahan oleh Bambang Sumantri). Gramedia. Jakarta.

Sukarno, A.A. 2014. Pengaruh Saat Pemberian dan Konsentrasi PGPR terhadap Pertumbuhan dan Hasil Tanaman Bawang Daun. Skripsi Universitas Pekalongan
Utami, M., Nawawi, M., dan M. D. Maghfoer. 2016. Respon Tanaman Kubis Bunga (Brassica oleracea var botrytis L.) yang Ditanam pada Lahan Setelah Tanaman Terong (Solanum melongena L.) yang Diperlakukan dengan Aplikasi Berbagai Kombinasi Sumber $\mathrm{N}$ dan EM4. Jurnal Produksi Tanaman Vol. 4 No. 7, Oktober 2016: 520527

Vandalisna dan S. Mulyono. 2015. Pembinaan Kelompok Tani Melalui Pembuatan dan Penggunaan Plant Growth Promoting Rhizobacteria (PGPR) pada Tanaman Selada (Lactuca sativa). Sekolah Tinggi Penyuluhan Pertanian (STPP) Gowa dan Balai Besar Pelatihan Pertanian (BBPP) Batangkaluku.

Widiatningrum T. dan K. K. Pukan. 2010. Pertumbuhan dan Produksi Kubis Bunga (Brassica oleracea var botrytis) dengan Sistem Pertanian Organik di Dataran Rendah. Jurnal Biosaintifika Volume 2 Hal 115-121. Universitas Negeri Semarang. 